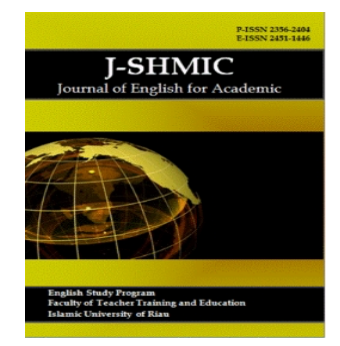

\title{
Students' Perceptions of Learning Platform: The Advantages and Disadvantages of Quipper School
}

\author{
Izen Diva ${ }^{1}$, Fauzul Etfita ${ }^{2}$ and Sri Wahyuni ${ }^{3}$ \\ Universitas Islam Riau ${ }^{1,2,3}$ \\ izendiva@student.uir.ac.id ${ }^{1}$; fauzuletfita@edu.uir.ac.id'; ; wahyunis@edu.uir.ac.id
}

\begin{abstract}
Quipper School is an online learning platform that consists of two portals, namely Learn for students and Link for teachers. The purpose of this study was to evaluate students' perceptions of the advantages and disadvantages of the Quipper School platform for English learning. This study was conducted at SMAN 3 Mandau, with a random sample of 52 students. This study used quantitative research and a questionnaire as the instrument. The questionnaire contains twenty questions, ten about the advantages and ten about the disadvantages. The findings of this study were quantitatively analyzed using the Likert scale formula. According to the results of the advantages questionnaire, the index percentage was $70 \%$. This demonstrates that students unanimously agree on the advantages of Quipper School. Additionally, the researchers discovered that the majority of students, $53 \%$, disagreed with statements about the disadvantages of Quipper School. This indicates that students do not perceive Quipper School to have any disadvantages. To summarize, the majority of students believed that Quipper School is an online learning platform that is beneficial for both teachers and students during the learning process, particularly when it comes to English learning.
\end{abstract}

\begin{abstract}
ABSTRAK
Quipper School adalah platform pembelajaran online yang terdiri dari dua portal, yaitu Learn untuk siswa dan Link untuk guru. Tujuan dari penelitian ini adalah untuk mengevaluasi persepsi siswa tentang kelebihan dan kekurangan platform Quipper School untuk pembelajaran bahasa Inggris. Penelitian ini dilakukan di SMAN 3 Mandau, dengan sampel acak sebanyak 52 siswa. Penelitian ini menggunakan penelitian kuantitatif dan instrumen berupa kuesioner. Kuesioner berisi dua puluh pertanyaan, sepuluh tentang keuntungan dan sepuluh tentang kerugian. Temuan penelitian ini dianalisis secara kuantitatif dengan menggunakan rumus skala Likert. Berdasarkan hasil kuesioner keunggulan, persentase indeks adalah 70\%. Hal ini menunjukkan bahwa siswa menyetujui keunggulan Quipper School. Selain itu, peneliti menemukan bahwa sebagian besar siswa, 53\%, tidak
\end{abstract}

\section{KEYWORDS advantages; disadvantages; perceptions; quipper school}

KATA KUNCI

kelebihan; kekurangan; persepsi; quipper school 
setuju dengan pernyataan tentang kekurangan Quipper School. Hal ini menunjukkan bahwa siswa tidak menganggap Quipper School memiliki kekurangan. Ringkasnya, sebagian besar siswa percaya bahwa Quipper School adalah platform pembelajaran online yang bermanfaat bagi guru dan siswa selama proses pembelajaran, terutama dalam hal pembelajaran bahasa Inggris.

\section{INTRODUCTION}

Nowadays, technology is such as a big thing in this world. Technology brings advantages and becomes the most important thing to live a life. In this era, people tend to use technology every single day since it helps a lot in their lives. In line with that information and science are expanding rapidly which gets that each activity can be accessed easily through a technology called the internet (Dağhan, 2017). The Internet has a positive point of view from people in this world, especially in education to develop the learning quality to be more effective, for example, the use of electronic learning in the teaching and learning process (Larchenko \& Barynikova, 2021).

Moreover, advances in technology have greatly affected the educational fields (Abdulrahaman et al., 2020). They mention that multimedia technology has been used widely in the education field. It helps the teacher and students for a great teaching and learning process because technology can create an optimized and efficient context to help students explore new ideas easier than before. Also, for the teacher, it can help the teaching and learning process easier to make the learning media an alternative way of learning for students.

Furthermore, technology plays a critical role that requires professionals, educators, and learners to reconsider their fundamental beliefs in order to use technology to redesign education and training systems (Etfita, 2018). However, the term electronic learning is frequently used in conjunction with one another to refer to the technological learning (Kumar Basak et al., 2018). Electronic learning facilitates the user to learn or to teach in an easy way, for example, to get the material or to share the material by using electronic media. One of electronic learning that can be used by electronic media nowadays is Quipper school, which has been used since 2014 until now in Indonesia. Quipper school was created to facilitate the learning process by providing access free to use. Quipper School is online learning (e-learning) platform designed to improve education by providing digital technology to teachers and students (Rasita Gloria Barus et al., 2021).

The use of e-learning offers cost-effective, easy to use, and increasing opportunities for lifelong learning which can be accessed anytime and anywhere. Also, Quipper school can be used in a variety of subjects, and the one that is English. Moreover, through Quipper School, teachers can send and manage learning materials, exams, and student grades (Mariam et al., 2022). Students can do homework, assignments, and online exams easily. Quipper school makes progress in the online learning process that makes it easy for students and teachers to think and share material. According to Jamil et.al (2019) Quipper School is already known as 
a new e-learning media. Quipper school has advantages and disadvantages. The advantages of Quipper school are the flexibility in time and place, ease, and free to use and make the students interested in learning (Syafrinata et al., 2021).

In SMAN 3 Mandau, the teachers have been using Quipper School as one of the learning platforms in the teaching process since 2015. Due to the Covid-19 pandemic, the teaching and learning process is currently one meeting every two weeks in each subject. As a result, the teacher combines face-to-face and online meetings. To maximize the effectiveness of teaching and learning, teachers utilize Quipper School as the learning platform for storing assignments, homework, and teacher-created materials. As defined by Wahyuni \& Etfita (2018), blended learning is the combination of online and face-to-face meetings. Due to the combination of online learning through Quipper school and face-to-face meetings. Students will take an interest in it if it provides them with something beneficial, as each individual has a natural tendency to deal with something in their environment. Thus, the researchers wanted to investigate the students' lack of interest and response to learning English material through the use of Quipper School as an e-learning platform by examining students' perceptions of the benefits and drawbacks of Quipper School.

\section{E-learning}

The teaching and learning process can be completed by utilizing e-learning. E-learning can help the teacher and student to communicate, think, and share the material anywhere and anytime. Arkorful \& Abaidoo (2014) state that e-learning refers to the use of information and communication technology to allow access to online learning tools. Second, e-learning has become an important tool of education for its productivity in delivering education with lower costs, for ease of use at any time and everywhere, and for solving many traditional educational issues, such as lack of classrooms and a shortage of faculty (Linjawi \& Alfadda, 2018).

So, from the explanation, it can be concluded that e-learning is one of the teaching media which support the rapid growth of online learning. Furthermore, e-learning refers to the use of information and communication technology to facilitate access to online learning tools.

\section{Quipper School}

According to Mahariyanti \& Suyanto (2018), one of the learning media in the form of electronic learning is Quipper School. Quipper School is a platform dedicated to students and teachers as an online learning medium. Quipper offers a ready-to-use web-based learning program that facilitates the teachers and students. It also supports teachers through virtual storage that allows them to upload and keep their PowerPoint presentations, PDF files, pictures and videos online (Mulyono,2016). Meanwhile, Septinawati et al (2020) mention that the use of Quipper School wants to modernize the way people study and exchange knowledge; Quipper School provides a fun way of online learning as it is believed that students learn in various ways. Moreover, Quipper School was created for online learning to make the teaching and learning process between the teacher and students easier and more fun.

Quipper School is provided into two portals, Quipper School Learn (learn.quipper.com) is a special portal where students can access and read course materials, answer questions, send a message to the teachers, and to see the performance of her classmates. Meanwhile, the Quipper School Link (link.quipper.com) is special portal for teachers where they can set up tasks, see the development of the students, send a message to students, manage the classroom, and make online classes. 


\section{Perception}

According to Samosir \& Gurning (2020), perception is related to the five senses which means see, hear or feel the object, and then we can provide our perception to that object. In line with that, Demuth (2013) explain that perceptions as objects which form the world's diversity, and the world's content, but also the primary source of sensual and intellectual cognition which will be the focus of ours thought. In addition, Akrim \& Sulasmi, (2020) state that the result of one's thoughts from certain situations is called perception. Furthermore, Qiong (2017) defines perception is about our five senses that sense of what happens around to recognize and identify to evaluate and then give meanings to what happens around.

Based on previous statements, it can be stated that perceptions can be in the form of responses or statements on things or events that they have experienced. Perception is someone's opinion or thought about something. To conclude, perception is about how someone sees what they've been through.

\section{METHOD}

This study employed a quantitative approach. According to Sukamolson (2007), several expert definitions of the quantitative method exist. Because quantitative research is primarily concerned with gathering numerical data to describe specific phenomena, specific questions appear to be well suited to being answered using quantitative methods. Quantitative research methods, according to Goertzen (2017), are aimed at gathering and evaluating data that can be represented numerically. One of the primary objectives is to develop accurate and reliable measures for statistical analysis.

Furthermore, the research population consists of eleventh-grade students from SMAN 3 Mandau. The total number of students in the eleventh grade is 396. The researchers chose to conduct this study through a random sampling of eleventh grade students at SMAN 3 Mandau. According to Arikunto (2006), if the subject has fewer than 100 participants, everyone should be taken; if the subject has more than 100 participants, $10 \%-15 \%, 20 \%-25 \%$, or more should be taken. The sample consisted of 52 students out of 396 , or $13 \%$ of the population. It requires $13 / 100396=51,48$.

This research utilizes a questionnaire as its instrument. The questionnaire is based on Yaghoubi et al (2008). The questionnaire contains twenty questions, ten of which address the advantages of e-learning and ten of which address the disadvantages of e-learning. This questionnaire utilized a five-point Likert scale ranging from 1 (strongly disagree) to 5 (completely agree) (strongly agree). The questionnaire was gathered via an online survey. According to Ary et al. (2010), an internet survey is conducted in the following manner: the researchers places the questionnaire on a website that the researchers creates, and the respondent answers the questions and submits the questionnaire online. The questionnaire question inquiries about students' perceptions of the advantages and disadvantages of the Quipper School platform for English learning.

Each student was provided with a questionnaire via Google Forms to facilitate completion. The data was collected via a questionnaire and analyzed to determine students' perceptions of the Quipper School platform's advantages and disadvantages. For the first time, after receiving the data, the researchers accessed the Google form to determine the percentage of respondents to the questionnaire. This research was conducted to ascertain the percentage of students who achieved a passing grade while using the Quipper School platform, but it interprets the data 
quantitatively using Microsoft Excel. The researchers calculated each student's individual score from the questionnaire using the Likert scale formula as follows:

$$
\mathrm{T} \times \mathrm{Pn}
$$

Description:

T: The total number of respondents who voted

Pn: Likert scale score numbers selection

Furthermore, to categorized each item of the questionnaire the researchers used formulation as follows (Pranatawijaya et al, 2019):

Total score $\quad=$ the sum of the results of each TxPn

Maximum score $=$ number of respondents $\mathrm{x}$ highest Likert score

Minimum score $=$ number of respondents $\mathrm{x}$ lowest Likert score

Indeks $(\%) \quad=($ Total score / Maximum score $) \times 100$

Moreover, rating interval in this research categorized as follows:

Strongly Agree : $87 \%-100 \%$

Agree $\quad: 70 \%-86 \%$

Neutral $\quad: 54 \%-69 \%$

Disagree $\quad: 37 \%-53 \%$

Strongly Disagree: $\leq 36 \%$

Meanwhile, since the researchers used Google form for the questionnaire, in the Google form menu there is a "summary" tab, that summary tab contains the percentage of respondents who voted. So, the results of the analyzed data have been seen on Google Form and the researchers processed the data, and then used the rating interval as previously explained.

\section{FINDING AND DISCUSSION}

To find out the students' perceptions of the Quipper School application, the researchers distributed questionnaires to students in the form of google online form. After that, the data gathered were analyzed by using a Likert scale. The questionnaire result in this study refers to the outcome of the questionnaire from two indicators, namely the advantages and disadvantages. Firstly, the researchers extracted the result from the google form and transferred it to Microsoft excel. After that, the researchers processed the data and applied the Likert scales formula. Finally, the data were processed and the findings are detailed in Table 1.

Table 1. Students' Perceptions of Quipper School

\begin{tabular}{|c|c|c|c|c|c|}
\hline Variables & Question & TOTAL & MAX SCORE & Index & CATEGORIZED \\
\hline Advantages(X1) & $\mathrm{X} 1.1$ & 197 & 260 & 76 & Agree \\
\cline { 2 - 6 } & $\mathrm{X} 1.2$ & 189 & 260 & 73 & Agree \\
\cline { 2 - 6 } & $\mathrm{X} 1.3$ & 181 & 260 & 70 & Agree \\
\cline { 2 - 6 } & $\mathrm{X} 1.4$ & 173 & 260 & 67 & Neutral \\
\cline { 2 - 6 } & $\mathrm{X} 1.5$ & 172 & 260 & 66 & Neutral \\
\cline { 2 - 6 } & $\mathrm{X} 1.6$ & 181 & 260 & 70 & Agree \\
\cline { 2 - 6 } & $\mathrm{X} 1.7$ & 170 & 260 & 65 & Neutral \\
\cline { 2 - 6 } & $\mathrm{X} 1.8$ & 182 & 260 & 70 & Agree \\
\cline { 2 - 6 } & $\mathrm{X} 1.9$ & 174 & 260 & 67 & Neutral \\
\cline { 2 - 6 } & $\mathrm{X} 1.1$ & 183 & 260 & 70 & Agree \\
\hline
\end{tabular}




\begin{tabular}{|c|c|c|c|c|c|} 
Disadvantages(X2) & X2.1 & 139 & 260 & 53 & Disagree \\
\cline { 2 - 6 } & X2.2 & 161 & 260 & 62 & Neutral \\
\cline { 2 - 6 } & X2.3 & 114 & 260 & 44 & Disagree \\
\cline { 2 - 6 } & X2.4 & 138 & 260 & 53 & Disagree \\
\cline { 2 - 6 } & X2.5 & 146 & 260 & 56 & Neutral \\
\cline { 2 - 6 } & X2.6 & 160 & 260 & 62 & Neutral \\
\cline { 2 - 6 } & X2.7 & 149 & 260 & 57 & Neutral \\
\cline { 2 - 6 } & X2.8 & 156 & 260 & 60 & Neutral \\
\cline { 2 - 6 } & X2.9 & 161 & 260 & 62 & Neutral \\
\cline { 2 - 6 } & X2.1 & 159 & 260 & 61 & Neutral \\
\hline
\end{tabular}

The Likert scale results for the advantages and disadvantages of the Quipper School platform as implemented in SMAN 3 Mandau are shown in Table 1. The majority of statements are classified as agree or neutral for the first indicator, advantages, with the agree category having a frequency of six and the neutral category having a frequency of four. There are six questions that fall into the 'agrees' category, such as the first, which inquires about Quipper School's flexibility in terms of learning time and location. Second, Quipper School enables students to easily share and respond to educational material. Then, Quipper School will demonstrate how it enhances students' teamwork and interaction with other students, as well as how it accommodates a variety of learning styles in order to maintain students' interest in learning. The following question is about Quipper School, which makes it simple for students to stay informed about educational material updates.

Besides, there are four questions classified as 'neutrals' in the advantages indicators, such as the one about Quipper School as an application that could boost students' confidence in enrolling in a college with all of the features provided. Following that, Quipper School increases students' interest in the possibility of working with e-learning and their responsiveness to the material. The final section contains questions about Quipper School, which instills students with confidence in their ability to study.

Additionally, Table 1 illustrates the result of the Quipper School platform's disadvantages. Out of ten questions, the majority of disadvantages are classified as neutral or disagree, with the neutral category receiving a score of seven and the disagree category receiving a score of three. There are seven 'neutral' questions; one of them is about Quipper School, which limits students' social and cultural interaction. The following question was, whether Quipper School has a slow internet connection when it is in use. Thirdly, there is the question of Quipper School, which requires users to pay an upfront fee to access the platform, and then there is the question of Quipper School being difficult to use for students with limited computer skills. Additionally, the question inquires about how Quipper School impairs students' productivity and how Quipper School impairs students' capacity for self-directed learning.

Moreover, there are three questions that have been classified as 'disagrees,' namely the first, in which students have technical difficulties accessing Quipper School, the second, in which Quipper School offers inappropriate content as e-learning, and the third, in which Quipper School lacks readiness in students learning to access. The researchers concluded that, based on their findings and explanations, the use of the Quipper School application is highly 
recommended for the teaching and learning processes. The findings indicate that students are interested in the Quipper School application. The findings are in line with what El Iq Bali et al., (2021) stated, they mention that Students' interest in learning is greater when using the Quipper School rather than using conventional learning.

\section{CONCLUSION}

According to the results of the Quipper School's advantages questionnaire, which included 52 students and ten questions, the advantages factor revealed that the majority of the questions were classified as agree or neutral, with six agrees and four neutrals. This means that the students experience the benefits of Quipper School when they attend SMAN 3 Mandau. Additionally, the results of the Quipper School's disadvantages questionnaire, which included 52 students and ten questions, indicated that the majority of the questions were classified as neutral disagree, indicating that students felt neutral or disagreed with the questionnaire's statements, which are divided into seven neutrals and three disagrees.

In general, the implementation of the Quipper School in SMAN 3 Mandau benefits or provides some benefits for their learning, particularly in learning English, such as the students' perception that Quipper School provides them with flexibility in terms of time and location for learning, and that Quipper School accommodates various types of learning styles to keep them interested in learning. Whereas, students in SMAN 3 Mandau felt that the majority of the statements about the disadvantages made by Yaghoubi et al (2008) were contradictory, as they did not perceive those statements as disadvantages.

\section{ACKNOWLEDGEMENTS}

I would like to express my honest appreciation to my advisor for providing me with the wonderful opportunity to write this wonderful paper, which also enabled me to undergo comprehensive research and learn about a tremendous amount of new information.

\section{REFERENCES}

Abdulrahaman, M. D., Faruk, N., Oloyede, A. A., Surajudeen-Bakinde, N. T., Olawoyin, L. A., Mejabi, O. V., Imam-Fulani, Y. O., Fahm, A. O., \& Azeez, A. L. (2020). Multimedia tools in the teaching and learning processes: A systematic review. Heliyon, 6(11), e05312. https://doi.org/10.1016/j.heliyon.2020.e05312

Akrim, A., \& Sulasmi, E. (2020). Talent Development \& Excellence Student Perception of Cyberbullying in Social Media. Talent Development and Excellence, 12(1), 322-333. http://www.iratde.com

Ary, D., Jacobs, L.C., \& Sorensen, C. (2010). Introduction to Research in Education $8^{\text {th }}$ Edition.

Dağhan, G. (2017). Views of Students about Technology, Effects of technology on Daily living and their Professional Preferences. Turkish Online Journal of Educational Technology, 16(4), 187-194.

Demuth, A. (2013). Perception Theories. Slovakies: kraków

Goertzen, M. J. (2017). Introduction to quantitative research and data. Library Technology Reports, 53(4), 12-18.

El Iq Bali, M. M., Zamroni, Umar, Musthofa, B., Sulistiani, I. R., Dewi, M. S., Baharun, H., 
\& Abdullah, D. (2021). The Effect of Quipper School Assisted Blended Learning (QSBL) on Student Motivation and Interest in Learning. Journal of Physics: Conference Series, 1899(1). https://doi.org/10.1088/1742-6596/1899/1/012154

Etfita, F. (2018). Students' Perspective on the Use of Edmodo as an Assessment Tool. $J$ SHMIC, 6(1), 18-25.

Jamil, W., Ampa, A. T., \& Ilmiah, I. (2019). The Students'learning Interest of Quipper School Used by the Teacher in Teaching English: Descriptive Research. Exposure: Jurnal Pendidikan Bahasa Inggris, 8(2), 141-157.

Kumar Basak, S., Wotto, M., \& Bélanger, P. (2018). E-learning, M-learning and D-learning: Conceptual definition and comparative analysis. E-Learning and Digital Media, 15(4), 191-216. https://doi.org/10.1177/2042753018785180

Larchenko, V., \& Barynikova, O. (2021). New technologies in education. E3S Web of Conferences, 273. https://doi.org/10.1051/e3sconf/202127312145

Linjawi, A. I., \& Alfadda, L. S. (2018). Students' perception, attitudes, and readiness toward online learning in dental education in Saudi Arabia: a cohort study. Advances in medical education and practice, 9, 855 .

Mahariyanti, E., \& Suyanto, S. (2019). The Effectiveness of using Quipper School Teaching Materials towards Students' Cognitive Outcomes of Eleventh Grade Students of MIPA. In 6th International Conference on Educational Research and Innovation (ICERI 2018) (pp. 44-47). Atlantis Press.

Mariam, S., Kepirianto, C., Fadhilah, M., \& Mardhiana, N. (2022). Utilizing Quipper School for Improving Reading Comprehension of Recount Text. Indonesian EFL Journal, 8(1), $127-136$.

Mulyono, H. (2016). Using Quipper as an online platform for teaching and learning English as a foreign language. Teaching English with Technology, 16(1), 59-70.

Pranatawijaya, V. H., Widiatry, W., Priskila, R., \& Putra, P. B. A. A. (2019). Penerapan Skala Likert dan Skala Dikotomi Pada Kuesioner Online. Jurnal Sains dan Informatika, 5(2), 128-137.

Rasita Gloria Barus, I., Bernadtua Simanjuntak, M., \& Sutrisno. (2021). Quipper School and Microsoft Teams-based Learning Material in English Class: Students' Perceptions (Study Case Taken from Saint Peter's Junior High School). Journal of Advanced English Studies, 4(2). https://doi.org/10.47354/jaes.v4i2.115

Qiong, O. U. (2017). A brief introduction to perception. Studies in Literature and Language, 15(4), 18-28.

Samosir, S. C., \& Gurning, L. (2020). Relationship Between the Perception and Skills of Student Basic Science Process in the Use of M-Module in Basic Physics Practicum. Jurnal Pena Sains Vol, 7(1).

Septinawati, S., Febriani, R. B., Tarwana, W., \& Syafryadin, S. (2020). Students' Perceptions Toward the Implementation of Quipper School as an E-Learning Platform in Teaching English. Jadila: Journal of Development and Innovation in Language and Literature Education, 1(2), 223-238.

Suharsimi, A. (2013). Prosedur Penelitian: Suatu Pendekatan Praktik. Jakarta: Rineka Cipta Sukamolson,S. 2007. Fundamentals of quantitative research. Language Institute Chulalongkorn University, 1(3), 1-20.

Syafrinata, D., Maksum, H., Padang, U. N., \& Sumatera, W. (2021). Development of Learning 
Media Using Quipper School Application On Maintenance Of Motorcycle. 6(2).

Wahyuni, S., \& Etfita, F. (2018). Pengaruh blended learning model dan sikap berbahasa terhadap kemampuan menulis bahasa inggris siswa sekolah menegah atas negeri di Kota Pekanbaru. GERAM, 6(2), 1-9.

Yaghoubi, J., Malek Mohammadi, I., Iravani, H., Attaran, M., \& Gheidi, A. (2008). Virtual Students' Perceptions of e-Learning in Iran. Online Submission, 7(3). 